九州大学学術情報リポジトリ

Kyushu University Institutional Repository

\title{
Effect of fungal Laccase and New Mediators, Acetovanillone and Acetosyringone, on Decolourization of Dyes
}

Cho, Hee-Yeon

Keck School of Medicine, University of Soutern California

Cho, Nam-Seok

School of Forest Resources and Rural Engineering, Chungbuk National University

Jarosa-Wilkolazka, Anna

Department of Biochemistry, Marie Curie-Sklodowska University

Rogalski, Jerzy

Department of Biochemistry, Marie Curie-Sklodowska University

他

https://doi.org/10.5109/9314

出版情報：九州大学大学院農学研究院紀要. 52 (2)，pp.275-280，2007-10-29. Faculty of Agriculture, Kyushu University

バージョン：

権利関係 : 


\title{
Effect of Fungal Laccase and New Mediators, Acetovanillone and Acetosyringone, on Decolourization of Dyes
}

\section{Hee-Yeon $\mathrm{CHO}^{1}$, Nam-Seok $\mathrm{CHO}^{2}$, Anna JAROSA-WILKOLAZKA ${ }^{3}$, Jerzy ROGALSKI ${ }^{3}$, Andrzej LEONOWICZ ${ }^{3}$, Yoo-Soo SHIN ${ }^{4}$ and Shoji OHGA*}

\author{
Laboratory of Forest Resources Management, Division of Forest Ecosphere Management, \\ Department of Forest and Forest Products Sciences, Kyushu University, \\ Sasaguri, Fukuoka 811-2415, Japan \\ (Received May 15, 2007 and accepted July 17, 2007)
}

\begin{abstract}
Several wood rotting fungi decolourized Remazol brilliant blue R (RBBR) and carminic acid (CA). Parallel activity of laccase in these fungi was studied. The addition of acetovanillone (AV) or acetosyringone (AS) intensified these processes: decolourization was more extensive than in the experiment omitting these compounds. At the presence of AS the decourization was more extensive than AV. However the level of destaining was relatively low in comparison to laccase activity on syringaldazine. The highly purified constitutive form of Cerrena unicolor and inducible form of Trametes versicolor laccases also decolourized both dyes. The fungus, Lentinus lepideus, which has no laccase activity did not decolourize at all. Nitrogen starvation induced the laccase and decolourization activity in both organisms, irrespective of nitrogen availability. This fact indicates laccase not solely responsible for decolourization, and probably decolourization of dyes involves more than one mechanism.
\end{abstract}

\section{INTRODUCTION}

Fungal laccases (benzenediol:oxygen oxidoreductases, EC 1.10.3.2) are multicopper oxidases, capable of reducing oxygen to water and simultaneously involved in oxidation of aromatic hydrogen donors. These enzymes and very similar polyphenol oxidases can be used as free or immobilized type both in water or in some organic solvents for improving several biotechnological processes (Burton et al., 1995; Luterek et al., 1998; Milstein et al., 1993). Of possible applications, the enzyme is considered as a bleaching agent in the pulp and paper industry (Bourbonnais et al., 1997), as a stabilizer during the must and wine processing (Lante $e t$ al., 1992) or as a dechlorinating agent in the effluent (Cho et al., 1999b; Roy-Arcand and Archibald, 1991). These blue copper enzymes not only oxidize phenolic compounds, but also decarboxylates them (Agematu et al., 1993), and modify their methoxyl groups by demethylation (Leonowicz et al., 1984) or demethoxylation (Leonowicz et al., 2000; Potthast et al., 1995). Those reactions play an important role in the initial transformation of lignin polymer (Leonowicz et al., 1999a). Laccase is also considered as bleaching agent of some industrial dyes (Schneider et al., 1999), but according to our recent findings the enzyme has a limited effect on decolorizing of dyes, mainly due to their oxidative specificity (Cho et al., 1999a; Leonowicz

\footnotetext{
1 Molecular Microbiology and Immunology, Keck School of Medicine, University of Southern California, Los Angeles, CA 90089, USA

2 School of Forest Resources and Rural Engineering, Chungbuk National University, Cheongju 361-763, Korea

3 Department of Biochemistry, Marie Curie-Sklodowska University, Lublin 20-031, Poland

${ }^{4}$ National Institute of Crop Science, RDA, Suwon, 441-857, Korea

* Corresponding author (E-mail: ohga@forest.kyushu-u. ac.jp)
}

et al., 1997).

The bleaching activity of Trametes versicolor was studied by Livernoche et al. (1981). In our earlier reports we have shown that the inducible form of laccase isolated from Kuechneromyces mutabilis and Pleurotus ostreatus decolourized carminic acid (CA, $\Delta_{\max }=465 \mathrm{~nm}, \mathrm{E}_{456}=919 \mathrm{M}^{-1} \mathrm{~cm}^{-1}$ ) (Cho et al., 1999a). On the other hand there have been studied that laccase could be bleachable hardwood pulp by depolymerizing and solubilizing lignin in the presence of so-called mediator compounds (Bourbonnais et al., 1995; Call, 1994). Therefore, in recent years, many studies have been focused on such potential low-molecular mediators, which posses high enough redox potentials ( $>$ $900 \mathrm{mV}$ ) to attack lignin by its migration into the lignified cell wall matrix. Examples of such substances include veratryl alcohol, oxalate, malate, fumarate, and 3-hydroxyanthranilic acid. Those compounds are produced as a result of fungal metabolism and their secretion enables the fungi to colonize and degrade the wood more effectively than the other organisms (Eggert et al., 1996; Hofrichter et al., 1998; Leonowicz et al., 1999a; Lundquist and Kirk, 1978; Traquair, 1987).

It was also found that delignification of kraft pulp by laccase can be supported by some low molecular compounds or other aromatic hydrogen donors as acting mediators, such as 2,2'azinobis-(3- ethylbenzenthiazoline-6-sulfonic acid) (ABTS) (Bourbonnais et al., 1995) or 1-hydroxybenzotriazole (HBT) (Call, 1994). The mediators were also used in bleaching of some industrial dyes with fungal laccase. For example direct blue 1 dye was decolourized by the enzyme containing culture filtrates through so-called mediation of two phenolic compounds - acetosyringone (AS) and methyl syringate (MS) (Schneider et al., 1999).

This study was carried out to examine discolourization of industrial dyes, such as Remazol brilliant blue $\mathrm{R}$ (RBBR, $\Delta_{\text {max }}=592 \mathrm{~nm}, \mathrm{E}_{592}=1,916 \mathrm{M}^{-1} \mathrm{~cm}^{-1}$ ) and carminic 
acid, by laccase enzyme from the some wood rotting fungi, with low molecular weight mediators, acetovanillone (AV) and acetosyringone (AS).

\section{MATERIALS AND METHODS}

\section{Organisms}

All fungal strains, Cerrena unicolor (Bull.ex Fr.) Murr., Gleophyllum odoratum (Wulf.ex Fr.) Imaz., Lentinus lepideus Fr., and Trametes versicolor (L.ex Fr.) Pil., were obtained from several fungal culture collections, the Fungal Culture Collection of the Department of Biochemistry, University of Lublin, Poland, registrated as FCL in the Information Center for European Culture Collections, Braunschweig, Germany, and the Fungal Culture Collections, School of Forest Resources, Chungbuk National University, Cheongju, Korea. The fungal cultures were maintained on $2 \%$ $(w / v)$ malt agar slants.

\section{Culture conditions and decolourization}

SMY-agar medium contained $10 \mathrm{~g}$ sucrose, $10 \mathrm{~g}$ malt extract, $4 \mathrm{~g}$ yeast extract and $20 \mathrm{~g}$ agar in $1000 \mathrm{ml}$ deionized water. Fungal strains were inoculated onto $20 \mathrm{ml}$ of SMY-agar medium containing $0.05 \%(\mathrm{w} / \mathrm{v})$ CA or $0.05 \%$ (w/v) RBBR and/or $10 \mu \mathrm{m} \mathrm{AV}$ and AS in $90 \mathrm{~mm}$ Petri dishes, and incubated at $27^{\circ} \mathrm{C}$. Fungal growth and decolourizing activities were measured as colony diameter and diameter of decolourized zone in $\mathrm{mm}$. The decolourization was evaluated three replications an each treatment.

\section{Determination of laccase and decolourizing activi- ties}

At the end of plate experiments, the culture fluids were separated from the mycelia by filtration. Laccase activity was measured with syringaldazine according to Leonowicz and Grzywnowicz (1981) at pH optimum for particular fungi, but with morpholineethane sulfonic acid buffer replaced by $0.1 \mathrm{M}$ (McIlvaine, 1921) citrate phosphate buffer as described Bollag and Leonowicz (1984). To exclude endogenous peroxide, the $10 \mathrm{~min}$. preincubation (stirring) of the enzyme sample with catalase $(10 \mathrm{mg} / \mathrm{ml})$ was performed. The laccase activity was calculated in nkat/litre.

Decolourizing activity was assayed with a standard reaction mixture containing of either $50 \mu \ell$ of $1 \mathrm{mM}$ RBBR or CA purified by gel filtration according to Ulmer et al. (1984), $250 \mu \ell$ of culture fluid or laccase in distilled water, and $200 \mu \ell$ of $0.2 \mathrm{M} \mathrm{Na-succinate} \mathrm{buffer}$ $(\mathrm{pH}$ 7.0). The concentration of each mediator, $\mathrm{AV}$ and AS, in the standard reaction mixture was $10 \mu \ell$, respectively. The decrease in absorbency was assayed at $592 \mathrm{~nm}$ for RBBR and $456 \mathrm{~nm}$ for CA. The activity was calculated in nkat per litre with using molar absorption coefficients $1916 \mathrm{M}^{-1} \mathrm{~cm}^{-1}$ for RBBR and $919 \mathrm{M}^{-1} \mathrm{~cm}^{-1}$ for CA, respectively, according to Eguchi et al. (1994).

\section{Nitrogen starvation of fungal cultures}

For the nitrogen starvation of the fungal cultures the method of Staszczak et al. (1996) based on mineral medium (Lindeberg and Holm, 1952) was employed. The mycelia were transferred to media deprived $L$-asparagine after 10 day incubation. Enzymatic activities were assayed $24 \mathrm{~h}$ after exchange of the media.

\section{Isolation and purification of constitutive laccase}

For the constitutive $C$. unicolor laccase purification, the method of Leonowicz et al. (1997) with some our and Gianfreda et al. (1998) modifications was applied. The modifications were as followed, the aerated cultures at the tops of laccase activity were filtered through Miracloth (Calbiochem, Lucerne, Switzerland). Each filtrate was desalted on the Sephadex G-25 column. The enzyme solutions were concentrated to ca. one tenth of the volume at $4^{\circ} \mathrm{C}$ with an Amicon ultrafiltration system equipped with a filter type PTGC (pore size 10,000 NMWL) and dialyzed 7 times to the deionized water and (before the end of dialysis) to $0.1 \mathrm{M}$ phosphate buffer, $\mathrm{pH} 6$. Then $25 \mathrm{ml}$ portions of enzyme preparations were applied onto the ConA-Sepharose columns $(7 \times 1.5 \mathrm{~cm})$, which were then washed with $0.1 \mathrm{M}$ phosphate buffer, until all unbound proteins were removed. The specifically bound proteins, including laccase, were eluted from the column with $20 \%$ sucrose (or, even better, with $10 \% \boldsymbol{\alpha}$-methyl mannoside) in $0.1 \mathrm{M}$ phosphate buffer, $\mathrm{pH} 6$. The fractions showing the highest laccase activity were concentrated by ultrafiltration, poured onto DEAE-Toyopearl column (25x $1.5 \mathrm{~cm}$ ) and eluted by a linear gradient of $0-0.35 \mathrm{M} \mathrm{NaCl}$ in $5 \mathrm{mM}$ TRIS/HCl buffer, $\mathrm{pH}$ 6.0. The fractions around the top of laccase activity, eluted by $\mathrm{NaCl}$ were collected, dialyzed to $0.5 \mathrm{mM}$ TRIS/HCl buffer, $\mathrm{pH} 6$ and applied onto a column of AH-Sepharose 4B coupled to syringaldehyde. The enzyme was eluted by $0.5 \mathrm{M}$ ammonium sulfate dissolved in the same buffer, $\mathrm{pH}$ 6.0, and stored as freeze-dried.

\section{Isolation and purification of inducible laccase}

The fermenter culture of $T$. versicolor based on Lindeberg and Holm (1952) medium was run at $28^{\circ} \mathrm{C}$ (Rogalski et al., 1990). To stimulate the production of inducible forms of laccase, ferulic acid was added as an inducer to the concentration of $0.2 \mathrm{mM}$ (Leonowicz et al., 1978). Isolation and preliminary purification of inducible laccase form by chromatography on Sephadex G-50 and DEAE-Sephadex A-50 columns were also done according to the method of Leonowicz et al. (1978). The further purification processes were same as in the case of constitutive laccase.

\section{RESULTS AND DISCUSSION}

\section{Decolourizing activities}

Aromatic dyes and phenols as well as mediators which are present in yeast extract caused in cultures inducible conditions. The results of decolourizing of fungi and its laccase activity are summerized in Table 1. The majority of used fungi showed the ability to remove colour from both RBBR and CA. The high decolouriza- 
Table 1. Decolourizing activity of fungi on RBBR and CA during $24 \mathrm{~h}$ plate test

\begin{tabular}{|c|c|c|c|c|c|c|c|c|c|}
\hline \multirow[t]{2}{*}{ Strain No. } & \multicolumn{3}{|c|}{$\begin{array}{c}\text { Decolourizing activity of } \\
\text { RBBR, mm }\end{array}$} & \multicolumn{3}{|c|}{$\begin{array}{l}\text { Decolourizing activity of } \\
\text { CA, mm }\end{array}$} & \multicolumn{3}{|c|}{$\begin{array}{c}\text { Laccase activity } \\
\text { nkat/l }\end{array}$} \\
\hline & Control & $\mathrm{AV}$ & $\mathrm{AS}$ & Control & $\mathrm{AV}$ & $\mathrm{AS}$ & Control & $\mathrm{AV}$ & $\mathrm{AS}$ \\
\hline C. unicolor & 8.7 & 9.2 & 9.6 & 9.5 & 10.7 & 11.6 & 1,324 & 1,377 & 1,387 \\
\hline G. odoratum & 10.9 & 12.3 & 13.1 & 15.3 & 17.5 & 18.2 & 3,874 & 3,998 & 4,024 \\
\hline L. lepideus & 0.0 & 0.0 & 0.0 & 0.0 & 0.0 & 0.0 & 0 & 0 & 0 \\
\hline T. versicolor & 9.8 & 10.1 & 10.9 & 12.3 & 14.2 & 16.1 & 1,212 & 1,253 & 1,249 \\
\hline
\end{tabular}

tion of RBBR and CA occured exclusively by fungi producing laccase. Further the addition of AV or AS to the cultures caused a quantitative improving the decolourizing. The decoloured zones were larger in the presence of AC than those without mediators (Table 1).

It has been shown that several polymeric dyes were decolourized by Phanerochaete chrysosporium under those conditions which favour lignin degradation, suggesting that the ligninolytic activity was responsible for the decolourization of these dyes (Glen and Gold, 1983; Spadaro et al., 1992). Besides, the most studies on $P$. chrysosporium, P. ostreatus (Kim et al., 1996; Platt et al., 1985; Shin et al., 1997; Vyas and Molitoris, 1995), Coriolus versicolor (Livernoche et al., 1981), Streptomyces sp. (Pasti and Crawford. 1991) and Geotrichum candidum (Kim et al., 1995) have been done for decolourizing activity. The fungi which have laccase activity were shown decolourization of RBBR and CA. It indicates the relationship between laccase and decolorization activity. The fungus, Lentinus lepideus, which has no laccase activity did not decolourize at all.

\section{Effect of purified laccase}

Table 2 and Table 3 show the results of purification of laccase from $C$. unicolor and $T$. versicolor at each purification step. The specific activities of first filtered solutions of two laccases are 42 nkat/mg and 53 nkat/mg, which are about 300 times higher than previously reported one (Gianfreda et al., 1998). Desalting and ultrafiltration could remove the other proteins and specific activities increased about 4 and 25 times, respectively. It is obvious that this procedure is very

Table 2. Isolation and purification of constitutive laccase from C. unicolor

\begin{tabular}{|c|c|c|c|c|}
\hline \multirow[b]{2}{*}{ Purification } & \multicolumn{2}{|c|}{ Activity } & \multirow[b]{2}{*}{$\begin{array}{c}\text { Yield } \\
(\%)\end{array}$} & \multirow[b]{2}{*}{$\begin{array}{l}\text { Purification } \\
\text { (fold) }\end{array}$} \\
\hline & $\begin{array}{c}\text { Total } \\
\text { (nkat/vol) }\end{array}$ & $\begin{array}{l}\text { specific } \\
\text { (total/mg } \\
\text { prot) }\end{array}$ & & \\
\hline Filtrate & 62,634 & 42 & 100 & 1.0 \\
\hline Sephadex G-25 & 38,792 & 83 & 61.9 & 2.0 \\
\hline Ultrafiltration & 34,627 & 167 & 55.3 & 4.0 \\
\hline ConA-Sepharose & 31,323 & 1,893 & 50.0 & 45.1 \\
\hline DEAE-Toyopearl & 7,982 & 3,067 & 12.7 & 73.0 \\
\hline $\begin{array}{l}\text { Syringyl-AH- } \\
\text { Sepharose 4B }\end{array}$ & 3,235 & 4,982 & 5.2 & 118.6 \\
\hline
\end{tabular}

effective and can remove low molecular weight proteins and the other small impurities. The main increases in specific activity were obtained after running various columns. The specific activities increased 118 and 100 times. The specific activity of 4,980 $-5,300 \mathrm{nkat} / \mathrm{mg}$ is one of the most active laccase ever reported (Heinzkill, 1998; Kim et al., 2002). The enzyme solution looks brownish blue color implying other brown colored proteins are still remained although the activity is quite high.

The results presented in Table 4 and Table 5 show that purified constitutive and inducible laccases decolourize both dyes. Decolourization was maximum in CA than RBBR. Furthermore, decolourization also increased by the use of mediators. As high amounts of laccase activities were applied (average about 8.2 times in the case of constitutive laccase of $C$. unicolor and about 8.5 times for $T$. versicolor inducible form of laccase as calculated from Tables 4 and 5), the decolorization did not coincide with laccase activity on syringaldazine, i.e. it increased much slower (maximum around 3 times without mediators and not more than 5 times with using mediators).

Further the nitrogen starvation method was introduced for the induction of ligninolytic activity in fungal cultures (Glenn and Gold, 1983). The manner of nitrogen starvation proposed by Staszczak et al. (1996) was applied. According to them, the changes into nitrogen deprived medium from nitrogen rich ones induces the secondary metabolism of fungi. Nitrogen starvation is known to induce the laccase production (Staszczak et al., 1999). Similarly low molecular aromatic compounds (mediators) were also known to increase the decolour-

Table 3. Isolation and purification of inducible laccase from $T$. versicolor

\begin{tabular}{|c|c|c|c|c|}
\hline \multirow[b]{2}{*}{ Purification } & \multicolumn{2}{|c|}{ Activity } & \multirow[b]{2}{*}{$\begin{array}{l}\text { Yield } \\
(\%)\end{array}$} & \multirow[b]{2}{*}{$\begin{array}{c}\text { Purification } \\
\text { (fold) }\end{array}$} \\
\hline & $\begin{array}{c}\text { Total } \\
\text { (nkat/vol) }\end{array}$ & $\begin{array}{c}\text { specific } \\
\text { (total/mg } \\
\text { prot) }\end{array}$ & & \\
\hline Filtrate & 15,276 & 53 & 100 & 1.0 \\
\hline Sephadex G-50 & 13,111 & 99 & 86.0 & 1.9 \\
\hline DEAE-Sephadex A-50 & 7,467 & 1,327 & 49.0 & 25.0 \\
\hline Ultrafiltration & 7,124 & 1,411 & 46.6 & 26.6 \\
\hline ConA-Sepharose & 6,074 & 1,899 & 40.0 & 35.8 \\
\hline DEAE-Toyopearl & 1,334 & 3,221 & 8.7 & 60.8 \\
\hline $\begin{array}{l}\text { Syringyl-AH- } \\
\text { Sepharose 4B }\end{array}$ & 522 & 5,311 & 3.4 & 100.2 \\
\hline
\end{tabular}


Table 4. Decolourizing activity of purified constitutive laccase

\begin{tabular}{|c|c|c|c|c|c|c|c|}
\hline \multirow{2}{*}{$\begin{array}{c}\text { Laccase } \\
\text { activity } \\
\text { nkat/l }\end{array}$} & \multicolumn{3}{|c|}{$\begin{array}{l}\text { Decolourizing activity } \\
\text { of RBBR, nkat/1 }\end{array}$} & \multirow{2}{*}{$\begin{array}{c}\text { Laccase } \\
\text { activity } \\
\text { nkat/l }\end{array}$} & \multicolumn{3}{|c|}{$\begin{array}{l}\text { Decolourizing activity } \\
\text { of CA, nkat/l }\end{array}$} \\
\hline & Control & $\mathrm{AV}$ & AS & & Control & $\mathrm{AV}$ & AS \\
\hline 737 & 1 & 15 & 19 & 815 & 17 & 46 & 67 \\
\hline 2,694 & 0 & 19 & 25 & 3,072 & 29 & 99 & 149 \\
\hline 6,120 & 1 & 48 & 51 & 6,412 & 54 & 142 & 315 \\
\hline $2,740 *$ & $0^{*}$ & $0 *$ & $0^{*}$ & $2,790^{*}$ & $0 *$ & $0^{*}$ & $0^{*}$ \\
\hline
\end{tabular}

* The enzyme preparations were boiled after measuring the activity with syringaldazine.

Table 5. Decolourizing activity of purified inducible laccase

\begin{tabular}{|c|c|c|c|c|c|c|c|}
\hline \multirow{2}{*}{$\begin{array}{c}\text { Laccase } \\
\text { activity } \\
\text { nkat/l }\end{array}$} & \multicolumn{3}{|c|}{$\begin{array}{l}\text { Decolourizing activity } \\
\text { of RBBR, nkat/l }\end{array}$} & \multirow{2}{*}{$\begin{array}{c}\text { Laccase } \\
\text { activity } \\
\text { nkat/l }\end{array}$} & \multicolumn{3}{|c|}{$\begin{array}{c}\text { Decolourizing activity } \\
\text { of CA, nkat/1 }\end{array}$} \\
\hline & Control & $\mathrm{AV}$ & AS & & Control & $\mathrm{AV}$ & AS \\
\hline 726 & 3 & 17 & 23 & 829 & 27 & 59 & 82 \\
\hline 2,763 & 5 & 22 & 31 & 3,115 & 45 & 125 & 197 \\
\hline 6,400 & 7 & 54 & 62 & 6,372 & 67 & 196 & 384 \\
\hline $2,900 *$ & $0 *$ & $0 *$ & $0 *$ & $3,213^{*}$ & $0 *$ & 0* & $0 *$ \\
\hline
\end{tabular}

* The enzyme preparations were boiled after measuring the activity with syringaldazine

ization activity (Schneider et al., 1999). These two inducing techniques were employed to understand the relationship between decolourization and laccase, using G. odoratum which produces laccase, and L. lepideus which does not produce laccase. The mediators significantly increased the decolourization in G. odoratum, then followed by L. lepideus (Tables 6 and 7). Among the mediators, the highest decolourization was recorded in AS than AV, irrespective of nitrogen availability (compare Table 6 and 7). Nitrogen starvation induced the laccase and decolourization activity in both organisms, respectively, This fact indicates laccase not solely responsible for decolourization. Probably decolourization of dyes involved by more than one mechanisms.

The results indirectly point that laccase, although shows decolourizing activity on RBBR and CA, is most probable not the only agent causing this process. The similar results were obtained earlier in the case of $P$. ostreatus and K. mutabilis fungi (Cho et al., 1999a). May be laccase supplements the activity of specific dye decolourizing enzymes similar to the enzyme reported by Vyas and Molitoris (1995). Such hydrogen peroxide dependent RBBR decolourizing enzyme was found in the solid-state culture of $P$. ostreatus in wheat straw. It seems that two decolourizing enzymes, specific and non-specific laccases, function in $P$. ostreatus (also in K. mutabilis, C. unicolor, T. versicolor and other fungi). The decolourizing activity of laccase on RBBR was reported earlier in the case of Pycnoporus cinnabarinus (Schliephake and Lonergan, 1996), $P$. ostreatus (Eguchi et al., 1994) and C. unicolor (Bekker et al., 1990). Also CA could be decolourized by laccase

Table 6. Laccase activities and RBBR and CA decolourizing activities in nitrogen rich cultures of $G$. odoratum and $L$. lepideus in the presence of mediators

\begin{tabular}{|c|c|c|c|c|c|c|c|}
\hline \multirow[t]{2}{*}{ Fungus } & \multirow{2}{*}{$\begin{array}{l}\text { Laccase } \\
\text { nkat/l }\end{array}$} & \multicolumn{3}{|c|}{$\begin{array}{l}\text { Decolourizing activity } \\
\text { of RBBR, nkat/1 }\end{array}$} & \multicolumn{3}{|c|}{$\begin{array}{l}\text { Decolourizing activity } \\
\text { of CA, nkat/l }\end{array}$} \\
\hline & & Control & $\mathrm{AV}$ & $\mathrm{AS}$ & Control & AV & AS \\
\hline G. odoratum & 4,213 & 22 & 81 & 98 & 123 & 312 & 396 \\
\hline L. lepideus & 0 & 3 & 3 & 10 & 29 & 45 & 79 \\
\hline
\end{tabular}

Table 7. Laccase activities and RBBR and CA decolourizing activities in nitrogen deprived cultures of $G$. odoratum and L. lepideus in the presence of mediators

\begin{tabular}{|c|c|c|c|c|c|c|c|}
\hline \multirow{2}{*}{ Fungus } & \multirow{2}{*}{$\begin{array}{l}\text { Laccase } \\
\text { nkat/l }\end{array}$} & \multicolumn{3}{|c|}{$\begin{array}{l}\text { Decolourizing activity } \\
\text { of RBBR, nkat/l }\end{array}$} & \multicolumn{3}{|c|}{$\begin{array}{c}\text { Decolourizing activity } \\
\text { of CA, nkat/ }\end{array}$} \\
\hline & & Control & $\mathrm{AV}$ & AS & Control & $\mathrm{AV}$ & AS \\
\hline G. odoratum & 7,340 & 34 & 121 & 144 & 378 & 1,197 & 1,372 \\
\hline L. lepideus & 0 & 8 & 15 & 21 & 89 & 134 & 157 \\
\hline
\end{tabular}


as shown earlier reports (Cho et al., 1999a; Eguchi et al., 1994). Our results presented here confirm that RBBR and CA can be decolourized by fungal laccases, both, constitutive and inducible. We were addictively shown that the decolourizing effect can be greatly improved by low molecular phenolics, AV and AS. Both compounds were earlier named "mediators" in the laccase context. Kim and Shin (2000) interpreting cyclic voltagrams of 23 different compounds included AV to the group of mediators which work lignin degradation with laccase. Schneider et al. (1999) reported that the decolourizing effect of laccase containing culture exctract on Direct Blue 1 dye was greatly improved by some phenolic compounds. Such unusual decolourizing activity of fungal laccase is not strange, as the enzyme shows very broad specificity for many hydrogen donors (Bollag \& Leonowicz 1994), including lignin. In this case the enzyme is known as a depolymerizing agent (Leonowicz et al., 1985; Leonowicz et al., 1999b; Potthast et al., 1995; Szklarz and Leonowicz, 1986). This laccase probably serves as a not specific but secondary agent. Laccase enzyme probably performs the analogical role in decolourizing process.

\section{CONCLUSIONS}

This study was carried out to examine discolourization of industrial dyes, such as Remazol brilliant blue $\mathrm{R}$ (RBBR, $\Delta_{\text {max }}=592 \mathrm{~nm}, \mathrm{E}_{592}=1,916 \mathrm{M}^{-1} \mathrm{~cm}^{-1}$ ) and carminic acid, by laccase enzyme from the some wood rotting fungi, with low molecular weight mediators, acetovanillone (AV) and acetosyringone(AS). The laccase shows decolourizing activity on RBBR and CA. It means laccase supplements the activity of specific dye, such as hydrogen peroxide dependent RBBR. The highly purified constitutive form of Cerrena unicolor and inducible form of Trametes versicolor laccases also decolourized both dyes. The addition of AV and AS improved the efficiency of dyes decolourization by wood rotting fungi and fungal laccase. Nitrogen starvation induced the laccase and decolourization activity in both organisms, irrespective of nitrogen availability.

\section{ACKNOWLEDGEMENT}

This work was supported by the Korea Research Foundation Grant (2001-042-G00015).

\section{REFERENCES}

Agematu, H., N. Shibamoto, H. Nishida, R. Okamoto, T. Shin and S. Murao 1993 Oxidative decarboxylation of 4-hydroxymandelic acid and 2- (4-hydroxyphenyl) glycine by laccase from Coriolus versicolor and bilirubin oxidases from Trachyderma tsunodae and Myrothecium verrucaria. Biosci. Biotech. Biochem., 58: 1877-1881

Bekker, E. G., S. D. Petrova, O. V. Ermolova, V. J. Elisashvili and A. P. Sinitsyn 1990 Isolation, purification and certain properties of laccase from Cerrena unicolor. Biokhimiya, 55: 2019-2024

Bollag, J. M. and A. Leonowicz 1984 Comparative studies of extracellular fungal laccases. Appl. Env. Microbiol., 48:
849-854

Bourbonnais, R., M. G. Paice, B. Freiermuth, E. Bodie and S. Boerneman 1997 Reactivities of various mediators and laccases with kraft pulp and lignin model compounds. Appl. Env. Microbiol., 63: 4627-4632

Bourbonnais, R., M. G. Paice, D. Reid, P. Lanthier and M. Yasuhi 1995 Lignin oxidation by laccase isozymes from Trametes versicolor and role of the mediator 2,2'-azinobis (3-ethylbenzthiazoline-6-sulfonate) in kraft lignin depolymerization. Appl. Env. Microbiol., 61: 1876-1880

Burton, S. G. and J. R. Duncan 1995 Activation of mushroom poly phenol oxidase in organic medium by the detergent SDS. Biotechnol Lett., 17: 627-630

Call, H. P. 1994 Process for modifying, breaking down or bleaching lignin, materials containing lignin or like substances. PCT World Pat. Appl. WO94/29510

Cho, N. S., J. M. Park, T. H. Choi, A. Matuszewska, M. Jaszek, K. Grzywnowicz, E. Malarczyk, K. Trojanowski and A. Leonowicz 1999a The effects of wood rotting fungi and laccase on destaining of dyes and KP bleaching effluent. Mokchae Konghak, 27: 72-79

Cho, N. S., J. Rogalski, M. Jaszek, J. Luterek, M. Woitas-Wasilevska, E. Malarczyk, M. Fink-Boots and A. Leonowicz 1996b Effect of coniferyl alcohol addition on removal of chlorophenols from water effluent by fungal laccase. J. Wood Sci., 45: 174-174

Eggert, C., U. Temp, J. F. D. Dean and K. E. Eriksson 1996 A fungal metabolite mediates oxidation of non-phenolic lignin structures and synthetic lignin by laccase. FEBS Lett., 391: $144-148$

Eguchi, F., A. Leonowicz, M. Higaki and T. Fukuzumi 1994 Laccase-less mutants induced by regeneration of protoplasts of Pleurotus Basidiomycetes. Mokuzai Gakkaishi, 40: $107-110$

Gianfreda, L., F. Sannino, M. T. Filazzola and A. Leonowicz 1998 Catalytic behavior and detoxifying ability of a laccase from the fungal strain Cerrena unicolor. J. Mol. Cat., 4: 13-23

Glenn, J. K. and M. H. Gold 1983 Decolorization of several polymeric dyes by the lignin degrading basidiomycete Phanerochaete chrysosporium. Appl. Env. Microbiol., 45: 1741-1747

Heinzkill, M., L. Bech, T. Halkier, P. Schneider and T. Anke 1998 Characterization of laccases and peroxidases from wood-rotting fungi (family Coprinaceae). Appl. Env. Microbiol., 64: 1601-1606

Hofrichter, M., D. Ziegenhagen, T. Vares, M. Friedrich, M. G. Jager, W. Frische and A. Hatakka 1998 Oxidative decomposition of malonic acid as basis for the action of manganese peroxidase in the absence of hydrogen peroxide. FEBS Lett., 434: 362-366

Kim B. S., S. J. Ryu and K. S. and K. S. Shin 1996 Effect of culture parameters on the decolorization of Remazol brilliant blue R by Pleurotus ostreatus. J. Microbiol., (Korea) 34: 101-104

Kim, S. Y., K. Ishikawa, M. Hirai and M. Shoda 1995 Characteristics of a newly isolated fungus, Geotrichum candidum, which decolorizes various dyes. J. Ferment. Bioeng., 79: 601-607

Kim, Y. S. and Shin, W. S. 2000 Electrochemical investigations of mediators for laccases in delignification. In Proc. Internat'l Symp. For. Sci., Chungbuk Nat. Univ., Cheongju, Korea, pp. $16-25$

Kim, Y. S., N. S. Cho, T. J. Eom and W. S. Shin 2002 Purification and characterization of a laccase from Cerrena unicolor and its reactivity in lignin degradation. Bull. Kor. Chem. Soc. 23(7): 985-989

Lante, A., A. Crapisi, G. Pasini, A. Zamorani and P. Spettoli 1992 Immobilized laccase for must and wine processing. In Annals of the New York Academy of Sciences Vol. 672, Enzyme Engineering 11. Eds. Clark, D. S. and Estell, D. A., pp. 558-561. The New York Academy of Sciences New York, New York

Leonowicz, A., A. Matuszewska, J. Luterek, D. Ziegenhagen, M. 
Wojtas-Wasilewska, N. S. Cho, M. Hofrichter and J. Rogalski 1999a Biodegradation of lignin by white rot fungi. Fungal Gen. Biol., 27: 175-185

Leonowicz, A. and K. Grzywnowicz 1981 Quantitative estimation of laccase forms in some white-rot fungi using syringaldazine as a substrate. Enzyme Microb. Technol., 3: 55-58

Leonowicz, A., G. Szklarz and M. Wojtas-Wasilewska 1985 The effect of fungal laccase on fractionated lignosulfonates (Peritan Na). Phytochemistry, 24: 393-396

Leonowicz, A., J. Rogalski, M. Jaszek, J. Luterek, M. Wojtas-Wasilewska, E. Malarczyk, G. Ginalska, M. Fink-Boots and N. S. Cho 1999b Cooperation of fungal laccase and glucose 1-oxidase in transformation of Björkman lignin and some phenolic compounds. Holzforschung, 53: 376-380

Leonowicz, A., J. Rogalski, E. Malarczyk, K. Grzywnowicz, G. Ginalska, J. Lobarzewski, S. Ohga, N. Pashenova, S. S. Lee and N. S. Cho 2000 Demethoxylation of milled wood lignin and lignin related compounds by laccase from white-rot fungus. Mokchae Konghak, 28: 29-40

Leonowicz, A., J. Trojanowski and B. Orlicz 1978 Induction of laccase in Basidiomycetes. Apparent activity of the inducible and constitutive forms of the enzyme with phenolic substrates. Acta Biochim. Polon, 25: 369-378

Leonowicz, A., L. Gianfreda, J. Rogalski, M. Jaszek, J. Luterek, M. Wojtas-Wasilewska, E. Malarczyk, A. Dawidowicz, M. Fink-Boots, G. Ginalska, A. Leonowicz and N. S. Cho 1997 Purification of extracellular Cerrena unicolor laccase by means of affinity chromatography. J. Korea Tappi, 29: 7-17

Leonowicz, A., R. U. Edgechill and J. M. Bollag 1984 The Effect on the transformation of syringic and vanillic acids by the laccases of Rhizoctonia praticola and Trametes versicolor. Arch. Microbiol., 137: 89-96

Lindeberg, G. and G. Holm 1952 Occurrence of tyrosinase and laccase in fruit bodies and mycelia of some Hymenomycetes. Physiol. Plantarum, 5: 100-104

Livernoche, D., L. Jurasek, M. Desrochers and L. A. Veliky 1981 Decolourization of a kraft mill effluent with fungal mycelium immobilized in calcium alginate beads. Biotechnol. Lett., 3 : 701-706

Lundquist, K. and T. K. Kirk 1978 De novo synthesis and decomposition of veratryl alcohol by a lignin-degrading basidiomycete. Phytochem., 17: 1676

Luterek, J., L. Gianfreda, M. Wojtas-Wasilewska, N. S. Cho, J. Rogalski, M. Jaszek, E. Malarczyk, M. Staszczak, M. Fink-Boots and A. Leonowicz 1998 Activity of free and immobilized extracellular Cerrena unicolor laccase in water miscible organic solvents. Holzforschung, 52: 589-595

McIlvaine, T. C. 1921 A buffer solution for colorimetric comparison. J. Biol. Chem., 49: 183-186

Milstein, O., A. Hüttermann, H. D. Ludemann, A. Majcherczyk and K. Schulze 1993 Transformation of lignin-related compounds with laccase in organic solvents. J. Biotechnol., $\mathbf{3 0}$ : $37-47$
Pasti, M. B. and D. L. Crawford 1991 Relationship between the abilities of streptomycetes to decolorize three anthrone-type dyes and to degrade lignocellulose. Can. J. Microbiol., 37: 902-907

Platt, M. W., Y. Hadar and I. Chet 1985 The decolorization of the polymeric dye poly-blue (polyvinylamine sulfonate-anthraquinone by lignin degrading fungi. Appl. Microbiol. Biotechnol., 21: 394-396

Potthast, A., T. Rosenau, C. L. Chen and J. S. Gratzl 1995 Selective enzymatic oxidation of aromatic methyl groups to aldehydes. J. Org. Chem., 60: 4320-4321

Rogalski, J., A. L. Dawidowicz and A. Leonowicz 1990 Purification and immobilization of extracellular laccase of the fungus Trametes versicolor. Acta Biotechnol., 10: 261-269

Roy-Arcand, L. and F. S. Archibald 1991 Direct dechlorination of chlorophenolic compounds by laccases from Trametes versicolor. Enzyme Microbiol. Technol., 13: 194-203

Shin, K. S., I. K. Oh and C. J. Kim 1997 Production and purification of Remazol brilliant blue $\mathrm{R}$ decolourizing peroxidase from the culture filtrate of Pleurotus ostreatus. Appl. Env. Microbiol., 63: 1744-1748

Schliephake, K. and G. T. Lonergan 1996 Laccase variation during dye decolourization in a 2001 packed-bed bioreactor. Biotechnol. Lett., 18: 881-886

Schneider, P., M. B. Caspersen, K. Mondorf, T. Halkier, K. Sko, P. R. Oestergaard, K. M. Brown, S. H. Brown and F. Xu 1999 Characterization of a Coprinus cinereus laccase. Enzyme Microbiol. Technol., 25: 502-508

Spadaro, J. T., M. H. Gold and V. Rendganatham 1992 Degradation of azo dyes by the lignin-degrading fungus Phanerochaete chrysosporium. Appl. Env. Microbiol., 58: 2397-2401

Staszczak, M., G. Nowak, K. Grzywnowicz and A. Leonowicz 1996 Proteolytic activities in cultures of selected white-rot fungi. J. Basic Microbiol., 36: 193-203

Staszczak, M., G. Nowak, N. S. Cho and A. Leonowicz 1999 A proteinases involved in the production of ligninolytic enzymes? In: Proc. International Sym. For. Sci., Chungbuk Nat. Univ., Cheongju, Korea, pp. 16-25

Szklarz, G. and A. Leonowicz 1986 Cooperation between fungal laccase and glucose oxidase in the degradation of lignin derivatives. Phytochem. 25: 2537-2539

Traquair, J. A. 1987 Oxalic acid and calcium oxalate produced by Leucostoloma cincta and L. personii in cultures and in peach bark tissue. Can. J. Bot., 65: 1952-1956

Ulmer, D. C., M. S. A. Leisola and A. Fiechter 1984 Possible induction of ligninolytic system of Phanerochaete chrysosporium. J. Biotechnol. 1: 13-24

Vyas, B. R. M. and H. P. Molitoris 1995 Involvement of an extracellular $\mathrm{H}_{2} \mathrm{O}_{2}$-dependent ligninolytic activity in the white-rot fungus Pleurotus ostreatus in the decolorization of Remazol brilliant blue R. Appl. Env. Microbiol., 61: 3919-3927 